UDC 658.8:347.715

JEL Classification: L83, M30, M31

http://doi.org/10.21272/mmi.2018.4-16

Laima Jeseviciute-Ufartiene,

Ph.D., Associate Professor, Vilnius Gediminas Technical University, Lithuania

llona Skackauskiene,

Ph.D., Professor, Vilnius Gediminas Technical University, Lithuania

\title{
IMAGE OF WOMEN'S VOLLEYBALL IN LITHUANIA PERCEIVING ITS CUSTOMER BEHAVIOUR
}

Abstract. Customer orientation is essential for long-term success competing between sports organizations in this dynamic business world. Perception of customer behaviour might be essential providing a competitive advantage of sport's organization. Customer orientation in strategy might increase customers' loyalty which is important for companies striving for survival and strengthening their competitiveness in the market. Customers' of sport's organization might behave differently according to the type of sport and even gender of sport's team. In this case, customers' (fans') behaviour of women's volleyball is analysed as an important factor in exploring its image. The aim of this article is to perceive the influence of the customers' behaviour in Lithuanian women's volleyball to its image. There was done sampling using a questionnaire with women's volleyball customers. So, we can suggest, that customer loyalty is related to the image of the sport's organization or team. The results of the research showed that women's volleyball is not a very popular sports game among Lithuanian people. Besides, according to the findings, the main customers of Lithuanian women's volleyball are retired professional players of volleyball and their family members. Thus, Lithuanian women's volleyball image has to be improved and firstly paying attention to customers' behaviour. Strong and statistically important Pearson correlation of the image of women's volleyball and public relations (as advertising and sharing information) shows that greater the image of women's volleyball needs greater attention and investment to public relations. Scientifically research results have a value of specific research of women's volleyball image in Lithuania. Furthermore, these research results could be applied to the practice of sports management while creating a strategy for the image of women's volleyball.

Keywords: customer behaviour, fans, the image of volleyball, management of women's sport.

Introduction. The image is one of the most important values of today's sports organization (Rak, 2015), which can influence the behaviour of all people involved with a sports organization (Ko et al., 2008). Each organization has a unique, positive or negative image (Moguluwa, Achor, 2012) that is created by the influence of consumer behaviour (Maščinskienè, Kuvykaitè, 2004; Atkočiūnienè, Boculo, 2011; Upamannyu, Sankpal, Gupta, 2015). Thus, Papaioannou, Macheimari, Kriemadis (2016) agree that customer orientation is essential for long-term success competing between sports organizations and surviving in this dynamic business world.

In today's competitive environment, any organization should think of its image while attracting and retaining customers (Obamiro, Ogunnaike, Osibanjo, 2014). Analyses showed (Skačkauskienè, VilkaitèVaitonè, Vojtovic, 2015) that customer's loyalty is important for companies striving for survival and strengthening their competitiveness. Customer loyalty plays a crucial role in ensuring a competitive advantage of a service provider because it is ten times less expensive for a business to retain its existing customers than to acquire new ones (Roy 2011). In addition, customer loyalty creates prerequisites for an increase in the market share, income, profit, strengthens business development and the image of the service provider (Terblanche, Boshoff 2010). Thus, customer-oriented strategy creates value for the customers and increases customers' loyalty which in turn results in sales growth and hence firm performance (Papaioannou, Macheimari, Kriemadis, 2016). Furthermore, sufficient analyses of customer's behaviour are essential for effective strategic management process (Petkovic, Jasinskas, JeseviciuteUfartiene, 2016).

Cite as: Jeseviciute-Ufartiene, L., \& Skackauskiene, I. (2018). Image of Women's Volleyball in Lithuania Perceiving its Customer Behavior. Marketing and Management of Innovations, 4, 179-190. http://doi.org/10.21272/mmi.2018.4-16 
Perception of customer behaviour might be essential providing a competitive advantage of sport's organization too. Image of organizations is essentially trying to differ from others and it is a competitive advantage (Abd-El-Salam, Shawky, El-Nahas, 2013). Accordingly, customer orientation in strategy might create value for customers and increase customers' loyalty (Papaioannou, Macheimari, Kriemadis, 2016).

Customer behaviour has been one of the most widely examined research areas within the realm of sport, with research focused on how fans as consumers are drawn or motivated to attend sporting events, purchase sports products, or exhibit other forms of consumer's behaviour (Keaton, Watanabe, Ruihley, 2015). But customers of sport's organization might behave differently according to the type of sport and even gender of sport's team (Keaton, Watanabe, Ruihley, 2015). Even more, the motivations and identifications displayed by consumers to sports entities can often change based on the type of sport and other factors. Because consumers display such a wide range of behaviour within a sports context, it is important that each group be specifically targeted through focused research and understanding (Keaton, Watanabe, Ruihley, 2015). In this case, customers' (fans') behaviour of women's volleyball is analyzed as an important factor in exploring its image. There are some researches about sports organization's image (Iconomescu, Mindrescu, Badau, 2014) and even women's volleyball (Zapalac, Zhang, Pease, 2010) where scientists noted about lack of researches analysing customer behaviour of women's volleyball. However, there are not much of the researches about sports organizations especially in Lithuania and its sports. Analyzing researches made by Lithuanian scientists (Virvilaitè, Dilys, 2010; Atkočiūnienè, Boculo, 2011) there could be mentioned that there are separate researches of image in the separate sports or sports organizations or male gender (Tabatabaeian, Khabiri, Rasooli, 2018; Žibinskaitè, 2009) without deep concentration on the aspects of consumer behaviour. Especially this lack of researches is felt in the popular sports - women's volleyball. For this reason, the scientific problem formulated in this article is how the behaviour of Lithuanian women's volleyball customers contributes to the image of women's volleyball.

The object of this article is the perception of customer's behaviour in women's volleyball. The goal of this article is to perceive the influence of the customer's behaviour in Lithuanian women's volleyball to its image. The aim of the article is achieved by two objectives:

1) to reveal customer's performance exploring the image in the sport;

2) to survey customer's behaviour influencing the image of women's volleyball in Lithuania.

Accordingly, there was used such methods as the sampling of the questionnaire, comparative analyses, content analyses, reliability analyses Cronbach-alpha, descriptive statistics as mean values and frequencies while analysing women's volleyball customers as respondents.

Literature review. The purpose of this section is to reveal customer's performance and customer behaviour that are related to the creation of sports organizations image according to the scientific literature review. Thus, firstly there is defined the concept of the image. Secondly, there is discussed the factors of the image and as one of the essential factors' consumer behaviour. Thirdly, there are revealed aspects of consumer behaviour that makes difference to the image of sport's organization. In scientific literature could be found several different definitions of organization's image. According to Busu (2013), the image is related to the organization's appearance and the network of relationships where it is created. The larger is the organization, the more activities it is performing, thus its image more depends on the relationship organization is able to create (Busu, 2013). There could be said that the image is networking and relations through other scientists (Upamannyu, Sankpal, Gupta, 2015) maintain that the image of an organization is a picture of an organization that is formed in the minds of different members of the society. Thus, there could be stated that the image is the picture created by members of the society.

Sarstedt, Wilczynski and Melewar (2012) defined the image of the organization as the result of the overall impression left by consumers in their minds, as a result of the accumulated feelings, ideas and experience of the organization, which is stored in memory and translated into positive or negative meaning (Sarstedt, Wilczynski, Melewar, 2012). Accordingly, there could be stated that Sarstedt, Wilczynski, 
Melewar (2012) and Upamannyu, Sankpal, Gupta (2015) definitions are kindly similar because all of them are talking about people's perception of an organization. People tend to think and analyze just the objects that they are interested in. There could be assumed that people in the image definitions are consumers of an organization or sport's organization. Analysing chronology of definitions (Table 1) there could be stated that organizations image is the certain moment or a picture of the organization that is created by the members of society: customers, competitors, suppliers, employees and other interest groups.

Table 1 - Chronologic definitions of organization's image

\begin{tabular}{|c|c|c|}
\hline Scientist & Definition & Relation to subject \\
\hline $\begin{array}{l}\text { Christensen, } \\
\text { Askegaard (2001) }\end{array}$ & $\begin{array}{l}\text { The overall impression made by the organization on its } \\
\text { influential groups. }\end{array}$ & Influential group \\
\hline $\begin{array}{l}\text { Maščinskienė, } \\
\text { Kuvykaitè (2004) }\end{array}$ & $\begin{array}{l}\text { It is a collection of unique associations that are formed at a } \\
\text { certain moment in the minds of consumers. These } \\
\text { associations represent what the current or potential user can } \\
\text { expect from the organization's goods or services. }\end{array}$ & Consumer \\
\hline $\begin{array}{l}\text { Upamannyu, Sankpal, } \\
\text { Gupta (2005) }\end{array}$ & $\begin{array}{l}\text { An imaginary organization image that is formed in the minds } \\
\text { of different members of society. }\end{array}$ & $\begin{array}{l}\text { Different members of the } \\
\text { society }\end{array}$ \\
\hline $\begin{array}{ll}\text { Smolen, } & \text { Pawlak } \\
(2006) & \end{array}$ & $\begin{array}{l}\text { A set of opinions shared by the organization's customers and } \\
\text { other entities directly or indirectly related to the organization, } \\
\text { and its staff. }\end{array}$ & $\begin{array}{l}\text { Customers and other } \\
\text { entities }\end{array}$ \\
\hline Price, Gioia (2008) & $\begin{array}{l}\text { It sends or receives perceptions of internal or external groups } \\
\text { about a particular organization. }\end{array}$ & Internal or external groups \\
\hline Ko et al. (2008) & $\begin{array}{l}\text { It is the impression of a specific segment of society about a } \\
\text { particular organization. The image of a sports or sports } \\
\text { organization has the potential to influence the behaviour of } \\
\text { all people involved with the sporting organization. }\end{array}$ & $\begin{array}{l}\text { A specific segment of } \\
\text { society }\end{array}$ \\
\hline $\begin{array}{l}\text { Atkočiūnienè, Boculo } \\
\text { (2011) }\end{array}$ & $\begin{array}{l}\text { It is a purposefully created or spontaneous derived form that } \\
\text { reflects a particular object in the minds of people. }\end{array}$ & People \\
\hline $\begin{array}{l}\text { Sarstedt, Wilczynski } \\
\text { and Melewar (2012) }\end{array}$ & $\begin{array}{l}\text { This is the general impression left by the consumer, as a } \\
\text { result of the accumulated feelings, ideas and experience of } \\
\text { the organization, which is stored in the memory and } \\
\text { transferred to a positive or negative meaning. }\end{array}$ & Consumer \\
\hline $\begin{array}{l}\text { Obamiro, Ogunnaike, } \\
\text { Osibanjo (2014) }\end{array}$ & $\begin{array}{l}\text { It is an impression perceived by the target groups. The image } \\
\text { is an organization's communication function or common } \\
\text { transaction signals that identify the perception of the } \\
\text { organization by customers, employees, the state, } \\
\text { competitors, suppliers, potential employees, and other } \\
\text { stakeholder groups. }\end{array}$ & $\begin{array}{l}\text { Target group: customers, } \\
\text { employees, the state, } \\
\text { competitors, suppliers, } \\
\text { potential employees, and } \\
\text { other stakeholder groups }\end{array}$ \\
\hline $\begin{array}{l}\text { Upamannyu, Sankpal, } \\
\text { Gupta (2015) }\end{array}$ & $\begin{array}{l}\text { It is a picture of an organization that is formed in the minds of } \\
\text { different members of society. }\end{array}$ & Members of the society \\
\hline
\end{tabular}

Sources: compiled by authors on the basis of Christensen, Askegaard (2001), Maščinskienè, Kuvykaitè (2004), Upamannyu, Sankpal, Gupta (2005), Smolen, Pawlak (2006), Price, Gioia (2008), Ko et al. (2008), Atkočiūnienè, Boculo (2011), Sarstedt, Wilczynski and Melewar (2012), Obamiro, Ogunnaike, Osibanjo (2014), and Upamannyu, Sankpal, Gupta (2015).

It is important to mention that the image of an organization is an inherited object that is passed from generation to generation (Smolen, Pawlak, 2006; Rindell, Edvardsson, Strandvik, 2010; Busu, 2013). The definition of the image is not static, and it evolves over time. It means that the definition of the image can expand in various directions. 
The analyses of the organization's image showed that the organization's image is influenced by various members of the society and vice versa these people are related to factors of organization's image too. Sarstedt, Wilczynski and Melewar (2012) have a different opinion about the form factors of the image. Some of them state that the image of an organization depends on leader's vision, formal organizational politics strategy, organizational culture, and identity of organization (Sarstedt, Wilczynski, Melewar, 2012). Others (Iconomescu, Mindrescu, Badau, 2014; Upamannyu, Sankpal, Gupta, 2015) declare that the core root of the image in an organization is a product or a service and their quality, relations with customers, social responsibility and ethics, the environment of an organization, and public relations. All these core root elements of the image in an organization could be divided into product-related and non-productrelated attributes. Blanka, Koenigstorferb and Baumgartnerc (2018) stated that both product-related and non-product-related attributes are important recognizing sports team brand and its image. Product-related attributes in sport are such as the success of the players. Non-product-related attributes are such as play halls and these attributes do not contribute to team performance but still impact the brand and its image (Blanka, Koenigstorferb and Baumgartnerc, 2018).

Tabatabaeian, Khabiri and Rasooli (2018) discussed that the image of the sports team is created in the mind of the customer according to his/her preferences, needs for purchase and loyalty to the brand. This creates a dynamic relationship between the sports team and the customer. Development of this relation forms a stream for self-efficacy, self-esteem and self-knowledge (Tabatabaeian, Khabiri, Rasooli, 2018). These aspects are essentially creating social relation with customer and forming the image of sport's team. Huang, Yen, Liu and Huang (2014) identifies the organization's image with eight factors that influence its formation, such as respect, professionalism, success, due appreciation, stability, reliability, firmness, and consumer care. One of the key factors in assessing the image of the organization is the quality of service. Yoshida (2017) marks an importance of understanding the quality of a sports consumer experience while developing the sports team brand as customer relates the quality in the sport with athletes' behaviour as a professional performance. Quality in the sport for customer occurs immediately after the service (Yoshida, 2017). Thus, only by understanding consumer needs and improving services will a positive image of the organization be gained, which will encourage consumer loyalty.

The organization's image may be positive or negative, false or fair, favourable or unfavourable (Moguluwa, Achor, 2012). What the organization does is reflected in its image and reputation. The image of an organization must be closely related or affected (positively or negatively) according to how the public perceives or sees the mission of the organization, culture or lifestyle, public relations (Moguluwa, Achor, 2012). It is important to pay attention that sport's organization is exclusive, and it has inherent specific stakeholders. There is known that a product has its customer target group thus sport has its fans, watchers, or followers (Robinson, France, 2011) that could be described as customers. Every sport's organization has to manage unique features of its business or sport's production and various participants in the market. Thus, the most important factors, that form and strengthen the image of sport's organization, are sport's organization players, their results and events of this sport's organization (Virvilaitè, Dilys, 2010).

These three factors depend on investments. Sport's teams are financed by many organizations that have a target to become known in the market through sport. There is the relation between the sport's team and its society. The society of sport's team consists of two groups: one group is customers (fans) and another group is stakeholders directly or indirectly connected to sport's team and its environment (Robinson, France, 2011). Thus, the society of sport's team becomes essential key getting investment for sport's team and important part creating the image of sport's team. Every organization has its specific customer which scope should be determined, analysed, and applied to strategical issues of organization management (Petkovic, Jasinskas, Jeseviciute-Ufartiene, 2016). There is important to find out how consumers develop a connection with specific sports organizations (Acimovic et al., 2013). This process includes the examination of how individuals build psychological connections with their teams, the 
importance of specific social factors such as the team's performance and characteristics, family socialization, peer socialization, geographic location of the individuals and the importance of media (Keaton, Watanabe, Ruihley, 2015). Specifically, it has been noted that the antecedents of team identity can influence the connection and involvement a fan has with a sporting entity.

Katz, Ward and Heere (2018) stated that the interpersonal relationships among fans may be more predictive of attendance behaviours than the well-studied individual-level attitudes. Relation of customers' attitudes is useful for understanding the performance, behaviours and beliefs and integrates individual and network level attributes. Thus, the behaviour of sport's customers (fans) could be thoroughly perceived (Katz, Ward and Heere, 2018). Sarstedt, Wilczynski and Melewar (2012) state that there is the relation between the image of the organization, its reputation, satisfaction of customers, and their loyalty. According to Zetou, Kouli and Psarras (2013), there is the relationship between customer's loyalty and targets of sport's organization. These targets are part of such tasks as growing the price, raising incomes, reducing costs and formatting a positive image of the organization. The customer's loyalty is assessed counting two factors: customers' frequency participating in the sport's events and customers opinion to certain sport's team and their reasons to attend events of this sport's team.

Sport's events attract customers (fans) and strongly influence the image of the sport's organization. Upamannyu, Sankpal and Gupta (2015) maintain that participation in the sport's events is related to positive emotional experience and feelings of customers (fans). Furthermore, Lee, Kim, Heere (2018) researched 7 emotional dimensions of customers' feelings such as connectedness, elation, competitiveness, surprise, anger, unhappiness, and worry. The results showed that all emotional dimensions are related to the team's brand, except anger, that had a dual (positive and negative) impact (Lee, Kim, Heere, 2018). This knowledge becomes even more important if we consider that various sport's events attract stakeholders. They found that all customers' emotional dimensions are related to the brand of holders (Alexandris, Kaplanidou, 2014). The manner, in which customers (fans) come to identify with their favourite teams, influence relation to the team, which then has a direct association with emotional outcomes and psychological effects (Upamannyu, Sankpal, Gupta, 2015). In essence, the development of a fan's interest in a team (including but not limited to family socialization, geography, team characteristics, athletic performance, or media) drives how and whether they think about, attend, and react to their favourite team's performance (Keaton, Watanabe, Ruihley, 2015).

For organizations to understand the behaviour of individuals there is a need to consider the motivations and outcomes which could potentially influence them to play sports related purchases and consume sportrelated media. Thus, there is a need to try and to identify behavioural, cognitive, and psychological factors that push individuals to identify with organizations, and thus help motivate them to consume sport (Keaton, Watanabe, Ruihley, 2015). According to Upamannyu, Sankpal and Gupta (2015), the image of the organization is based on physical and behavioural characteristics. Physical features include the name of the organization, the structure, the variety of products and services. Behavioural features include impressions of communication quality communicated through interaction with clients. The image of the organization has two main factors: first, it is a functional factor (Palacio, Meneses, Perez, 2002) that includes material properties, and the other is emotional (Palacio, Meneses, Perez, 2002; Veljkovic, Petrovic, 2011), related to the psychological aspects, which manifest itself in assessing the feelings and attitude of the organization (Richard, Zhang, 2012). Perception of psychological aspects supports the idea that managers of sport's teams should pay more attention to the creation of a long-term relationship with customers (fans) and less attention to advertising and looking for sponsorship (Mašala et al., 2009). Thus, public long-term relations while creating positive emotions during sport's events becomes essential for creating and forming the image of the sport's organization. Accordingly formed image would form way formed image would attract investors.

Research methodology. As the image of volleyball team is assumed and assessed according to its 
customers' opinion (Yeo, Goh, Tso, 2011; Huang et al., 2014) the respondents of the research were chosen fans of Lithuanian women volleyball competition. As in Keaton, Watanabe and Ruihley (2015) research, customers are more influenced by family when choosing a favourite team. Customers' interest in women's volleyball is personal and influenced by family culture. Thus, there could be stated that respondents were deeply introduced with this game and its management. For this reason, they were assumed as experts of women's volleyball.

The research questionnaire was made from 14 questions gathered from different scientific researches:

1. Demographic questions were chosen according to Zapalac, Zhang and Pease (2010) offered customers' segmentation by age, gender, education.

2. Factors that show customers engagement to watch the competition of women's volleyball team as the loyalty of customer (Zapalac, Zhang, Pease, 2010; Zetou, Kouli, Psarras, 2013).

3. Questions that allow finding out the customers' opinion about volleyball's image in Lithuania (Virvilaitè, Dilys, 2010).

Questions were formed using the Likert scale from ' 1 ' to ' 5 ' where ' 1 ' had meaning of 'totally disagree' and ' 5 ' had meant 'totally agree' that is the most often used by other researches (Yeo, Goh, Tso, 2011). The sample size was counted according to Lithuania situation that during women's volleyball competition in the hall there are about 150 fans. Using $95 \%$ of confidence level, $5 \%$ of errors and $50 \%$ of response distribution, the sample size was 109 respondents. There were gathered 112 filled questionnaires. 0.919 Cronbach Alfa of the questions (excluding demographic data) shows the credibility of the made research.

Research results. Demographic data of the research shows that women's volleyball customer is a young (18-29-year-old) single educated person, either men or women. The research results showed that $63 \%$ of respondents watch women's volleyball because they are playing themselves this game at the moment and $18 \%$ of them used to play this game couple years ago or in their childhood (2\%) or are learning to play this game now $(3 \%)$. Another reason why respondent became the fan of women's volleyball is that his/her family member $(5 \%)$ or friend $(2 \%)$ is playing in the team. Just $2 \%$ of respondents mentioned that they do not have relation themselves with the volleyball gameplay. Customer loyalty is related to the image of the sport's organization or team. Thus, looking at the research results (fig. 1) there could be stated that customer of women's volleyball is a very active fan at home hall because $30 \%$ of them watch the competition 1-3 times a week, $32 \%$ of them watch it 1-3 times a year.

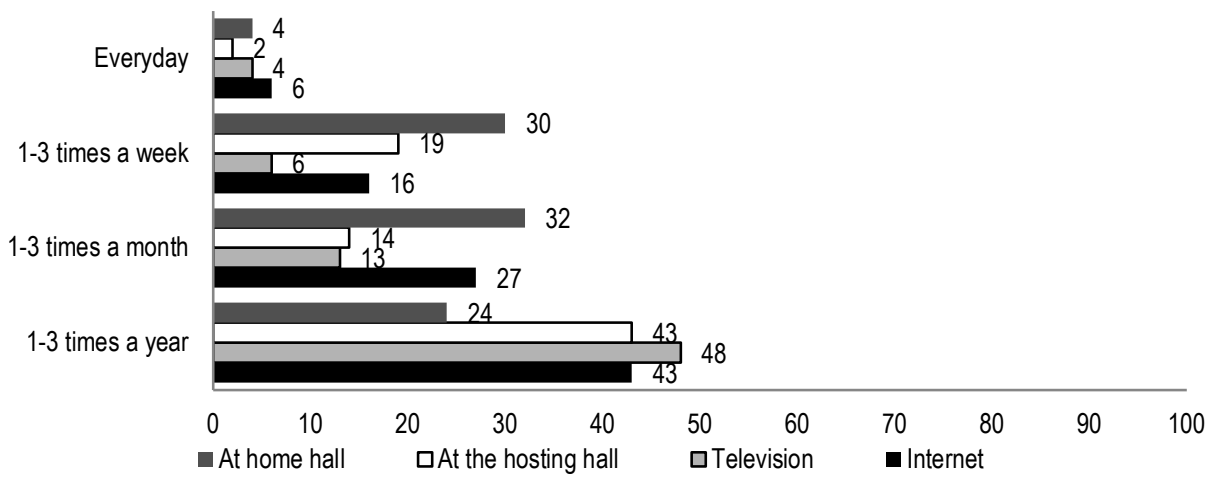

Figure 1 - Customers' loyalty according to their activeness watching competition (percentage grouped from four questions)

Sources: compiled by authors on the basis of the research data

According to research's data, customers prefer watching the live play of volleyball because $48 \%$ of 
respondents watch the volleyball game through TV just 1-3 times a year and just $6 \%$ of them watch it 1-3 times a week. Usage of the internet is more popular watching women's volleyball (fig. 1.) but still watching the game at the home hall or even at the hosting hall is more popular. Thus, the place and the view of hall might be important gaining satisfaction of women's volleyball customer.

Customer loyalty and thus attractiveness to be part women's volleyball team could be caused by different reasons. The research data show (fig. 2) that the most important reason to become a fan (customer) of women's volleyball is a close relation of the person to women's volleyball players or their teams. According to research data, it is very important for the customer to get 'Possibility to watch the game for free' (mean value is 4.12) and this is true if we count that respondents declare watching the competition as 'a good way to spend time' (mean value is 3.92 ).

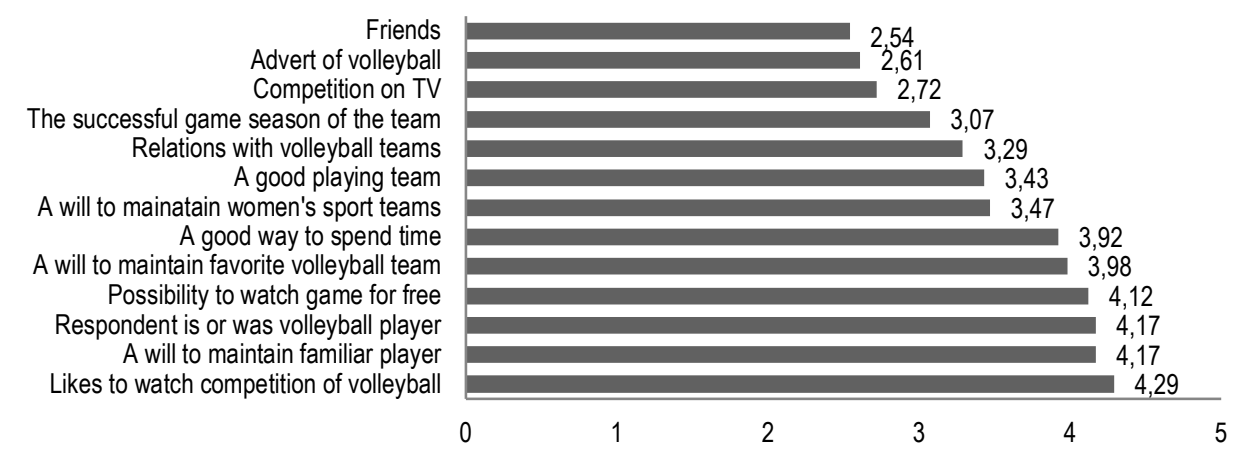

Figure 2 - Factors that show customers engagement to watch the competition of women's volleyball team as the loyalty of customer (mean values)

Sources: compiled by authors on the basis of the research data

It is not very important who is playing volleyball women or men because the mean value of the reason 'a will to maintain women's sports teams' is just 3.47. At the same time the research results show and confirm that customers are not very interested in watching volleyball on the TV (mean value is 2.72 ) or they are not influenced by adverts (mean value is 2.61) or by their friends (mean value is 2.54). The research data shows that respondents assessed dissemination of information just 3.67 (mean value from fig. 3).

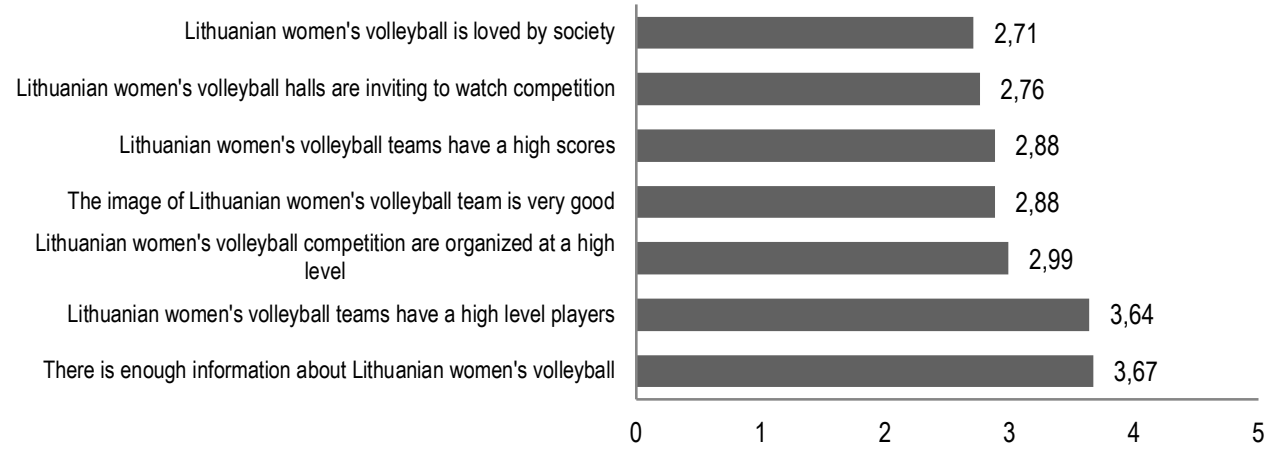

Figure 3 - The customers' opinion about volleyball's image in Lithuania (mean values) Sources: compiled by authors on the basis of the research data 
From figure 2 we have information that respondents are not influenced by the advert. According to these two results and respondents' opinion that Lithuanian women's volleyball is not loved by society (mean value is just 2.71 in fig. 3), there could be stated that women's volleyball is not very popular sports game among Lithuanian people. Thus, Lithuanian women's volleyball image has to be improved and firstly paying attention to customers' behaviour. The research data showed (fig. 4) that respondents relate the image of women's volleyball with sports results (mean value is 4.60 in fig. 4), athletes (4.37), sponsors (4.36) and public relations (4.29). Thus, there could be stated that the achievements of athletes, club sponsorship and public relations strongly affect the image of women's volleyball. Management of sport's organization (4.16), sports equipment (4.08) and sport's halls (4.04) are forming the image of women's volleyball more than the culture of sport's organization (3.71 in fig. 4).

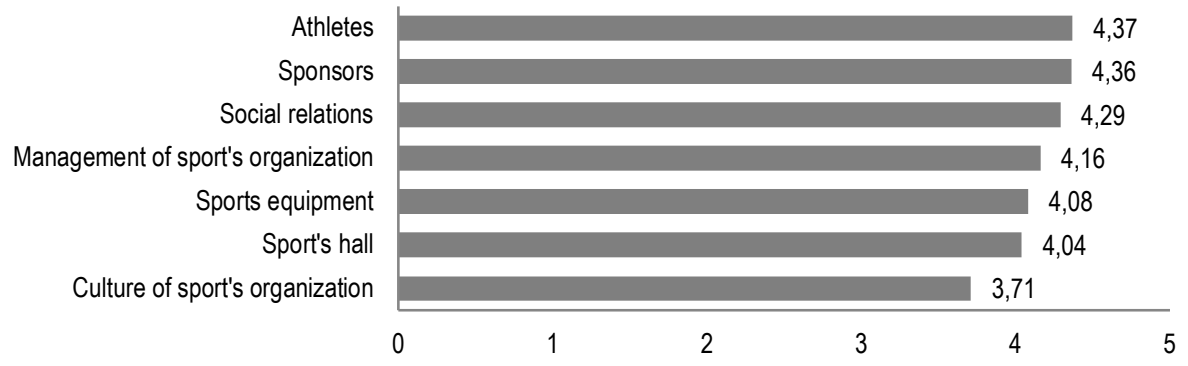

Figure 4 - Factors that are importantly creating the image of Lithuanian women's volleyball (mean values)

Sources: compiled by authors on the basis of the research data

0,719 (when the correlation is significant at the 0.01 level) strong and statistically important Pearson correlation of the image of women's volleyball and public relations (as advertising and sharing information) shows that greater the image of women's volleyball needs greater attention and investment to public relations.

Respondents evaluated statement 'Lithuanian women's volleyball teams have a high-level players' just as partly consistent (mean value 3.64 in fig. 3). But the strong and statistically important Pearson correlation $(0,746$ when the correlation is significant at the 0.01 level) between this statement and the image of women's volleyball showed that high scored players of women's volleyball are important purposefully attracting customers and improving the image of women's volleyball.

Discussion. Research results confirmed Blanka, Koenigstorferb and Baumgartnerc (2018) statement that both product-related and non-product-related attributes are important recognizing sports team brand and its image. Emotional relation of the customer with the team athletes as a product-related attribute (Blanka, Koenigstorferb, Baumgartnerc, 2018) was identified. The results of the research showed that the main customers of Lithuanian women's volleyball are retired professional players of volleyball and their family members and these results confirm the research results found by Keaton, Watanabe and Ruihley (2015). It could be stated that the customer of women's volleyball is emotionally related with this kind of sport as it is analyzed as one of the important factors influencing customer behaviour (Palacio, Meneses, Perez, 2002; Veljkovic, Petrovic, 2011). There could be stated that the image of women's volleyball could be improved by creating a deeper relationship with the customer and expanding the number of customers who would be emotionally related to this sport. The research results in this article are very similar to the research made by Zapalac, Zhang and Peace (2010) - in both types of research there was found that men and women are the same interested to watch the women's volleyball game. At the same time, both 
research results showed that the customer of women's volleyball feels strong relation with the team. As it was found in the research results (Lee, Kim, Heere, 2018) sports consumers are attached to their teams. Positive brand emotions are at the heart of the consumer meanings (Lee, Kim, Heere, 2018). Thus, recognized emotional connection between customer and women's volleyball team kindly supports that the strength of women's volleyball image is related to the positive emotions of the customer.

The research results in this article on some aspects are similar to the research made by Zapalac, Zhang and Peace (2010). In both types of research respondents outlined as the most important aspects to watch the women's volleyball game such as 'likes to watch the competition of volleyball' and 'possibility to watch the game for free (see table 2). It is interesting to mention that Lithuanian respondents less than respondents of Zapalac, Zhang and Peace (2010) were interested in women's volleyball because of 'A will to maintain women's sport team' and more interested because of 'a will to maintain a familiar player' or 'Respondent is or was volleyball player'. Thus, it could be stated that Lithuanian women's volleyball is very emotionally related to its customer. Importance of sport's hall identified as a non-product-related attribute (Blanka, Koenigstorferb, Baumgartnerc, 2018) in the research results. The research results in this article are very similar to the research made by Zetou, Kouli and Psarras (2013) because in both types of research were found that home hall to watch the game is more popular than the outbound competition. Scientists (Palacio, Meneses, Perez, 2002; Zapalac, Zhang, Peace, 2010; Veljkovic, Petrovic, 2011; Zetou, Kouli, Psarras, 2013) recommend working on creating close, deep and strong relationships between customers and playing the team with the purpose to develop the image of sport's organization. This factor is identified as specific to an image of a sport's organization. According to research data (see fig. 4), smart management of women's volleyball could improve the image of Lithuania women's volleyball. These research results are related with the statement of Mašala, Šunje, Rado and Bonacin (2009) that a proper management and purposeful development of the management model of a sports organization can become the main factors in the success of a sports organization. Furthermore, Smolen and Pavlak (2006) point out that the positive image of the sports organization is necessary in order to gain a competitive position in the sports market. Professionals who are well-versed in the sports market need to plan and create a sports organization's image in a systematic and continuous way.

Table 2 - Comparison of the research data

\begin{tabular}{|l|c|c|}
\hline \multicolumn{1}{|c|}{ Aspects of customer behaviour } & $\begin{array}{c}\text { Article research data } \\
\text { (see fig. 2) }\end{array}$ & $\begin{array}{c}\text { Research data of Zapalac, } \\
\text { Zhang and Pease (2010) }\end{array}$ \\
\hline Likes to watch the competition of volleyball & 4.29 & 4.14 \\
\hline Possibility to watch the game for free & 4.12 & 4.21 \\
\hline A will to maintain a familiar player & 4.17 & 3.74 \\
\hline Respondent is or was a volleyball player & 4.17 & 3.29 \\
\hline A will to maintain favourite volleyball team & 3.98 & 3.99 \\
\hline A good way to spend time & 3.92 & 3.93 \\
\hline A will to maintain women's sport team & 3.47 & 4.11 \\
\hline The successful game season of the team & 3.07 & 3.29 \\
\hline A good playing team & 3.43 & 3.95 \\
\hline
\end{tabular}

Sources: compiled by authors on the basis of the research data and Zapalac, Zhang and Pease (2010)

Conclusions. The examination of consumer (fan) behaviour has been considered an important part because it is noted that understanding how individuals behave in their consumption patterns can allow organizations to behave in a more strategic manner. The article research results showed that customers are active when the volleyball team is playing at home hall and their activeness is related to the volleyball team, players, and facilities of watching environment. Thus, customers (fans) are the very important creating image of women's volleyball. According to the respondents' opinion there were found very strong 
and statistically significant correlation among the image of women's volleyball and several factors as sport's events, sport's facilities, and team players. The value of these factors is important to customers. Thus, improvement of sport's events, sport's facilities, and team players would create higher value for women's volleyball image. The results of the research showed that the main customers of Lithuanian women's volleyball are retired professional players of volleyball and their family members. Even more, the comparison of the research data with the similar researches revealed that the image of women's volleyball as the image of any sport's organization is strong emotional relation between sport's team and its customers. Thus, development of this relation could improve positively the image of women's volleyball in Lithuania.

Acknowledgement. The authors of this article are very grateful to women's volleyball player Neringa Grikstaite for her help in gathering research data.

\section{References}

Abd-El-Salam, E.M., Shawky, A.Y., El-Nahas, T. (2013). The impact of corporate image and reputation on service quality, customer satisfaction and customer loyalty: testing the mediating role. Case analysis in an international service company. The Business \& Management Review, 3(2), pp. 177-196. Available: http://www.abrmr.com/myfile/best_track/best_track_48526.pdf

Acimovic, D., Spirtovic, O., Jonic, Z., Projevic, A. (2013). Organizational Structure of Management in Sport and its Significance for Achieving Sport Results. Activities in Physical Education and Sport, 3(2), pp. 251-253. Available: http://fsprm.mk/wpcontent/uploads/2014/06/251-253.pdf [Accessed September 11, 2018]

Alexandris, K., Kaplanidou, K. (2014). Marketing sport event tourism: sport tourist behaviors and destination provisions. Sport Marketing Quarterly, Special Issue: Marketing Sport Event Tourism, 23(3), pp. 125-126. Available: https://search.proquest.com/openview/5578bc7bd2657feb5ac0615626eabb9a/1?pq-origsite=gscholar\&cbl=28711

Atkočiūnienè, V., Boculo, I. (2011). Lietuvos kaimo vietoviu ivaizdžio formavimo valdymas. Ekonomika ir vadybas: aktualijos ir perspektyvos, 4(24), pp. 31-41. Available: https://vb.asu.lt/object/elaba:6090918/6090918.pdf [Accessed October 2, 2018]

Blanka, A.S., Koenigstorferb, J., Baumgartnerc, H. (2018). Sport team personality: It's not all about winning! Sport Management Review, 21, pp. 114-132. Doi: http://dx.doi.org/10.1016/j.smr.2017.05.004

Busu, O. V. (2013). Social Image and Brand Image of Organization. Business Management Dynamics, 3(3), pp. 22-26. Available: <http://bmdynamics.com/issue_pdf/bmd110399-\%2022-26.pdf > [Accessed September 15, 2018]

Huang, C.C., Yen, S.W., Liu, C.Y., Huang, P.Ch. (2014). The Relationship Among Corporate Social Responsibility, Service Quality, Corporate Image And Purchase Intention. The International Journal of Organizational Innovation, 6(3), pp. 68-84. Available: http://www.ijoi-online.org/attachments/article/38/FINAL_ISSUE_VOL_6_NUM_3_JANUARY_2014.pdf

Iconomescu, M., Mindrescu, V., Badau, D. (2014). Importance of Human Resources in Sports Clubs and in Sports Performance Management. Scientific Journal of Education, Sports, and Health, 2(15), pp. 269-278. Available: http://gymnasium.ub.ro/index.php/journal/article/view/99 [Accessed September 20, 2018]

Katz, M., Ward, R.M., Heere, B. (2018). Explaining attendance through the brand community triad: Integrating network theory and team identification. Sport Management Review, 21, pp. 176-188. Doi: http://dx.doi.org/10.1016/j.smr.2017.06.004

Keaton, S.A., Watanabe, N.M., Ruihley, B.J. (2015). What Types of SportFans use Social Media? The Role of Team Identity Formation and Spectatorship Motivation on Self-Disclosure during a Live Sport Broadcast. ResearchGate, pp. 2-30. Available: https://www.researchgate.net/profile/Shaughan_Keaton/publication/283461584_What_Types_of_SportFans_use_Social_Media_T he_Role_of_Team_Identity_Formation_and_Spectatorship_Motivation_on_Self-

Disclosure_during_a_Live_Sport_Broadcast/links/5638ecd808aed5314d221651/What-Types-of-SportFans-use-Social-Media-TheRole-of-Team-Identity-Formation-and-Spectatorship-Motivation-on-Self-Disclosure-during-a-Live-Sport-Broadcast.pdf

Ko, Y. J., Kim, K., Claussen, C. L., Kim, T.H. (2008). The effects of sport involvement, sponsor awareness and corporate image on intention to purchase sponsors' products. International Journal of Sports Marketing \& Sponsorship, pp. 79-94.

Lee, S., Kim, Y., Heere, B. (2018). Sport team emotion: Conceptualization, scale development and validation. Sport Management Review, 21, pp. 363-376. Doi: http://dx.doi.org/10.1016/j.smr.2017.08.007

Mašala, A., Šunje, A., Rado, I., Bonacin, D. (2009). Analysis of Innovative Model of Functional Roles and Levels of Sports

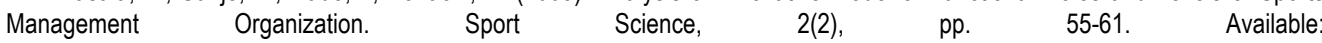
https://www.researchgate.net/profile//zet_Radjo2/publication/267807778_Analysis_of_innovative_model_of_functional_roles_and_I evels_of_sports_management_organization/links/546084300cf2c1a63bfdf4cd.pdf [Accessed September 5, 2018]

Maščinskienè, J., Kuvykaitè, R. (2004). Markès svarba formuojant prekès ivaizdi. Organizaciju vadyba: sisteminiai tyrimai, 30 , pp. 123-134. Available: http://web.b.ebscohost.com/ehost/pdfviewer/pdfviewer?vid=1\&sid=56238dd9-57db-4eab-bc2e67b5e0cee874\%40sessionmgr104 [Accessed September 22, 2018] 
Moguluwa, Sh. Ch., Achor, P. N. (2012). Mega-Events, Corporate Image \& Reputation: Preliminary Insights from Nigeria. African Journal of Business and Economic Research, 7(2-3), pp. 155-170. Available: http://web.b.ebscohost.com/ehost/pdfviewer/pdfviewer?vid=9\&sid=18917dae-060e-4e81-838c-398d51776fba\%40sessionmgr102

Obamiro, J.K., Ogunnaike, O.O., Osibanjo, O. A. (2014). Organizational Citizenship Behaviour, Hospital Corporate Image and Performance. Journal of Competitiveness, 6(1), pp. 36-49. Doi: https://doi.org/10.7441/joc.2014.01.03

Palacio, A.B., Meneses, G.D., Perez, P.J. (2002). The configuration of the university image and its relationship with the satisfaction of students.Journal of Educational Administration, 40(5), pp. 486-505. Doi: https://doi.org/10.1108/09578230210440311

Papaioannou, A., Macheimari, K., Kriemadis, Th. (2016). The relationship between customer oriented strategy and organizational performance in Professional sports. ResearchGate, pp. 69. Available: http://www.easm.net/download/2016/Therelationship-between-customer-oriented-strategy-and-organizational-performance-in-professional-sports.pdf

Petkovic, J., Jasinskas, E., Jeseviciute-Ufartiene, L. (2016). Significance of strategic planning for results of sport organization. E \& M Ekonomie a management, 19(4), pp. 56-72.

Rak, A. (2015). Brand and corporate image of a sport organisation as a factor of building loyalty on example of rock climbing in Poland. International journal of Innovation and Learning, 17(2), pp. 205-216. Doi: https://doi.org/10.1504/IJIL.2015.067408

Richard, J. E., Zhang, A. (2012). Corporate image, loyalty, and commitment in the consumer travel industry. Journal of Marketing Management, 28(5-6), pp. 568-593. https://doi.org/10.1080/0267257X.2010.549195

Rindell A., Edvardsson B., Strandvik T. Mapping the Roots of Consumer's Image-in-use of Companies, Journal of Product and Brand Management, Vol.6, pp. 423-431, 2010. Doi: https://doi.org/10.1108/10610421011085730

Robinson, S., France, A. (2011). Comparing Sports Marketing of Amateur Team Sports to Professional Team Sports. Journal of Applied Business Research, 9(1), pp. 47-61. Available: https://trove.nla.gov.au/work/160755335

Roy, S. (2011). Brand loyalty measurement: a framework. SCMS Journal of Indian Management, 8(2), pp. 112-122.

Sarstedt, M., Wilczynski, P., Melewar, T.C. (2012). Measuring reputation in global markets - A comparison of reputation measures' convergent and criterion validities. Journal of World Business, 49, pp. 329-339. Doi: https://doi.org/10.1016/j.jwb.2012.07.017

Skačkauskienè, I., Vilkaitè-Vaitonè, N., Vojtovic, S. (2015). Model for measuring customer loyalty towards a service provider. Journal of business economics and management. 16(6), pp. 1611-1699.

Smolen, A., Pawlak, Z. (2006). Image Building of Commercial Sports Organizations. Research yearbook, 12(2), pp. 309-312. Available: $\quad$ http://web.b.ebscohost.com/ehost/pdfviewer/pdfviewer? vid=11\&sid=ddca67a9-df8f-4986-9c5a9ecd76add592\%40sessionmgr102 [Accessed September 2, 2018]

Tabatabaeian, F., Khabiri, M., Rasooli, M. (2018). Brand Personality of the Premier League of Iran's Soccer - Strategies and Consequences. Annals of Applied Sport Science, 6(2), pp. 87-9.

Terblanche, N.S., Boshoff, C. (2010). Quality, value, satisfaction and loyalty among race groups: a study of customers in the South African fast food industry. South African Journal of Business Management, 41(1), pp. 1-9.

Upamannyu, N.K., Sankpal, Sh., Gupta, M. (2015). Effect of Corporate Image on Brand Trust and Brand Affect. Management Edge, 8(1), pp. 28-41. Available: http://web.b.ebscohost.com/ ehost/pdfviewer/pdfviewer?vid=2\&sid=2e0915a6-948b-4b6a-b621b56ad11e9d91\%40sessionmgr120 [Accessed September 2, 2018]

Veljkovic, D., Petrovic, D. (2011). The Role of Corporate Image In The Process Of Company Takeovers. Megatrend Review,

8(1), pp. 77-93. Available: http://web.a.ebscohost.com/ehost/pdfviewer/pdfviewer?vid=1\&sid=efba9401-1d15-45d9-96fa5360a14be715\%40sdc-v-sessmgr03 [Accessed October 2, 2018]

Virvilaitè, R., Dilys, M. (2010). Formatting Sport Organization Image as a Competitive Advantage Trying to Attract More Sponsors. Engineering Economics, 21(5), pp. 561-567. Available: www.inzeko.ktu.lt/index.php/EE/article/download/11724/6392

Yeo, R.K., Goh, M., Tso, S. (2011). Corporate image and reputation of large Mainland Chinese enterprises. Journal of Marketing Communications, 17(3), pp. 195-211. Doi: http://dx.doi.org/10.1080/13527260903421466

Yoshida, M. (2017). Consumer experience quality: A review and extension of the sport management literature. Sport Management Review, 20, pp. 427-442. Doi: https://doi.org/10.1016/j.smr.2017.01.002

Zapalac, R.K., Zhang, J.J., Pease, D.G. (2010). Understanding women's collegiate volleyball spectators from the perspectives of sociodemographic, market demand and consumption level. International Journal of Sports Marketing \& Sponsorship, 11(4), pp. 50-73. Doi: https://doi.org/10.1108/lJSMS-11-04-2010-B005

Zetou, E., Kouli, O., Psarras, A. (2013). The Role of Involvement in the Loyalty of Sport Fans in Professional Volleyball. International Journal of Sport Management Recreation \& Tourism,12, pp. 1-16. Doi: 10.5199/ijsmart-1791-874X-12a

Žibinskaitè, E (2009). Women's basketball team of Vytautas Magnus University: subcultural identity. Grupès ir aplinkos, 1, pp. 261-274. Available: https://vb.vdu.It/object/elaba:6136609/6136609.pdf [Accessed September 10, 2018]

Л. Джейсевічуйте-Уфартіен, Ph.D., доцент, Вільнюський технічний університет Гедимінас (Литва);

I. Скаккаускіене, Ph.D., доцент, Вільнюський технічний університет Гедимінас (Литва).

Вплив споживчої поведінки на імідж жіночого волейболу в Литві

Орієнтація на клієнта є основною для довгострокового успіху спортивних організацій, що конкурують між собою в умовах турбулентного бізнес-середовища. За таких умов врахування поведінки споживачів $є$ необхідним для забезпечення конкурентної переваги спортивної організації. Стратегія орієнтації на клієнта може сприяти підвищенню лояльності 
споживачів, що є важливим для компаній, які прагнуть до виживання та зміцнення конкурентоспроможності на ринку. Клієнти спортивної організації можуть поводити себе по-різному, залежно від виду спорту та навіть статі спортивної команди. У статті аналізуеться поведінка споживачів (вболівальників) жіночого волейболу як важливий чинник у вивченні його іміджу. Мета статті полягає у визначенні впливу поведінки споживачів жіночого волейболу Литви на його імідж. Авторами було проведено вибіркове дослідження за допомогою опитування клієнтів жіночого волейболу. Результати дослідження свідчать, що основними споживачами литовського жіночого волейболу $є$ в минулому професійні гравці з волейболу та їх члени родини. Було встановлено, що імідж спортивної організації чи команди впливає на лояльність споживачів. Результати опитування також свідчать про незначну популярність жіночого волейболу серед населення Литви. У зв'язку з цим, імідж жіночого волейболу в Литві має покращуватись, в першу чергу, шляхом вивчення поведінки споживачів. Досить велике значення коефіцієнту кореляції Пірсона між іміджем жіночого волейболу і зв'язками з громадськістю (наприклад, реклама й обмін інформацією) підтверджує необхідність більш уважного ставлення до іміджу жіночого волейболу та інвестування у зв'язки з громадськістю. Результати статті $\epsilon$ важливими для дослідження іміджу жіночого волейболу в Литві. Крім цього, отримані результати можуть бути застосовані в практиці спортивного менеджменту при формування стратегії покращення іміджу жіночого волейболу.

Ключові слова: поведінка споживачів, шанувальники, імідж волейболу, управління жіночим спортом.

Manuscript received: 25.09.2018

(C) The author(s) 2018. This article is published with open access at Sumy State University. 